\title{
The Indo-Pak Rivalry over Kashmir Issue: An Analysis of Past and Present of Kashmir
}

\section{La rivalidad indo-pakistaní sobre Cachemira: Un análisis del pasado y presente de Cachemira}

Shamaila Amir

Hamdard University - Pakistan

Karachi, Pakistan

shaminhasan@hotmail.com

Muhammad Asadullah

Bahauddin Zikria University - Pakistan

Multan, Pakistan

zainkhan92@gmail.com

Eva Rodríguez Agüero

Karakorum University Gilgit - Pakistan

Gilgit, Baltistan, Pakistan

dawoodkarimo11@gmail.com

Fayyaz Ahmad

National University of Science and Technology - Pakistan

Islamabad, Pakistan

fayyaz7522@gmail.com

\section{ABSTRACT}

The Kashmir issue, a principal reason for rivalry between India and Pakistan, has become the atomic flashpoint and a constant threat to the security of South Asia. The aim of this paper is to highlight the root causes of Kashmir disputes and the major events that contributed towards the Indo-Pak rivalry with respect to Kashmir. The paper highlights present political conditions in the Indian-held Kashmir also shows the role of India, Pakistan, and the United Nations in Kashmir Dispute. In the end, a conclusion is presented for the devalued relations of India and Pakistan in the setting of Kashmir and its effects are analyzed.

Keywords: Kashmir, Indo-Pak rivalry, security, South Asia, Human Right violations

\section{RESUMIEN}

La cuestión de Cachemira, una de las principales razones de la rivalidad entre la India y el Pakistán, se ha convertido en el punto álgido atómico y en una amenaza constante para la seguridad del Asia meridional. El objetivo de este documento es poner de relieve las causas fundamentales de las disputas de Cachemira y los principales acontecimientos que contribuyeron a la rivalidad indo-pakistaní con respecto a Cachemira. El documento pone de relieve las condiciones políticas actuales en la Cachemira controlada por la India y muestra también el papel de la India, el Pakistán y las Naciones Unidas en la controversia sobre Cachemira. Al final, se presenta una conclusión para las relaciones devaluadas de la India y el Pakistán en el escenario de Cachemira y se analizan sus efectos.

Palabras clave: Cachemira, rivalidad indo-pakistaní, seguridad, Asia meridional, violaciones de los derechos humanos 


\section{Introduction}

South Asia is no doubt the most militarized area of the world because of India and Pakistan which are not only neighbors but nuclear powers and rivals also. The whole region of South Asia is traumatized by their rivalry. When analyzed, it is clear that this rivalry is principally due to the faulty distribution of boundaries between the two countries which at the time of partition created structural asymmetry. On top of this faulty distribution stands the regions of Kashmir which was acceded to India (Figure 1) making the already complex strategic environment of South Asia further aggravated (Hussain et al., 2019). This issue is an ever-increasing rift between the relations and cause of many crises these two states, sometimes directly and many times indirectly. Where India does not pay any heed to the Kashmiris right of self-determination and the political efforts by Pakistan have not yielded significant results, the UN's indecisiveness and ignorance to this issue have turned it into a great threat to the security of South Asia. This rivalry between the two countries cannot be reduced without solving this issue (Bhat, 2017; Braithwaite \& Dcosta, 2018; Buzan, 2011).

Figure 1. A photograph from The Hindustan Times about the settlement

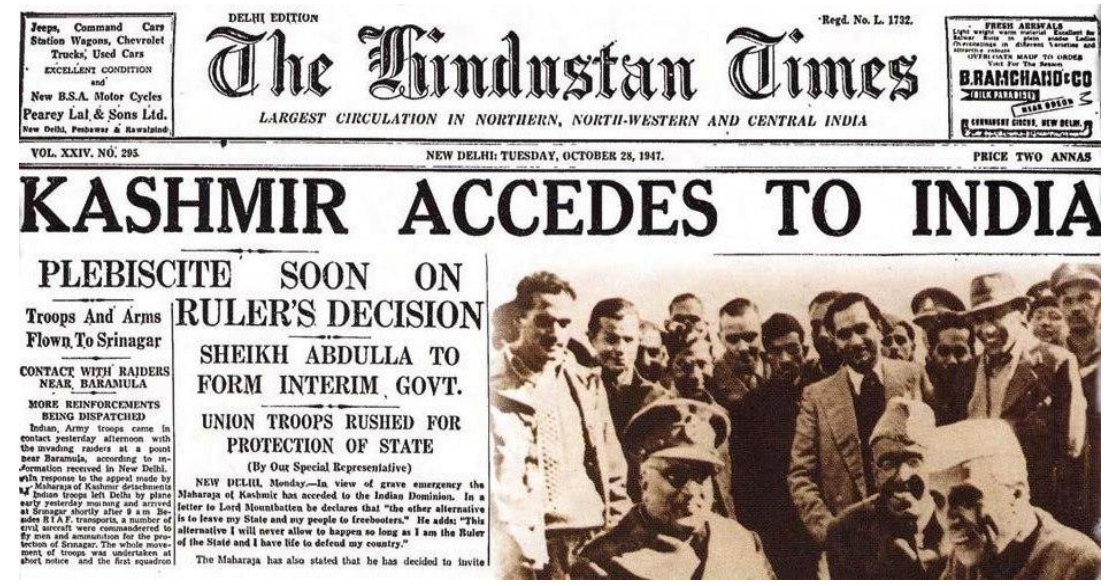

Source: (Kashmir Global, 2012)

\section{Kashmir before the Partition of India and Pakistan}

The map of Kashmir shows the distributions and claims over the various parts of the valley (Figure 2). At the time of partition of India and Pakistan, the ruler of the state of Jammu and Kashmir was Maharaja Gulab Singh, the founder of the "Dogra Dynasty" (Hussain et al., 2019). This dynasty was characterized by autocracy and sectarianism, and therefore the people of the state did not enjoy the "freedom of expression and speech." In 1932, the "All Jammu and Kashmir Muslim Conference" was established and Sheikh Mohammad Abdullah became its first president. Later in 1939, this conference was converted into National Conference to facilitate the non-Muslim Kashmiris to join it but till mid-140, the politics of Kashmir remained full of controversies and contestations and its main reason was the strong ties between Sheikh Abdullah and Congress (Aurangzeb et al, 2020; Naz, 2019; Ali \& Saeed, 2019; Hussain et al., 2019). As at that time the differences between the identities of Muslims and Hindus were at their peak, the popularity of the National Conference started vanishing. Despite that, Sheikh Abdullah was not ready to dissolve National Conference into the Muslim Conference. He was also not willing to terminate his strong relations with Congress. On the other hand, Nehru who was concerned deep into the Kashmir affairs visited Kashmir along with some Muslim leaders. The purpose of this visit was to build a "positive image of Congress as a national party" which was supported by “enlightened Muslim leaders" (Hussain et al., 2019). In 1944, the National Conference formulated an economic and social plan for Kashmir which was known as "Naya (New) Kashmir" (Hussain et al., 2019). This plan was submitted to the Maharaja of the state, Hari Singh. According to this plan which it was suggested that the absolute monarchy must be transformed into absolute democracy in the state of Jammu and Kashmir. The economic design of this plan was also adopted by the National Conference as their party manifesto. Sheikh Abdullah, in 1946, led the "Quit Kashmir Move- 
ment" but this movement was criticized by the Congress leaders and also the "mainstream of Kashmiri Pandits" who were associated with the National Conference (Hussain et al., 2019; Bhat, 2017). However, "Nehru defended the case of Sheikh Abdullah" and interfered with the internal affairs of the state. He was arrested while attempting to enter the state through Rawalpindi (on 19th of June, 1946). Meanwhile, Muhammad Ali Jinnah declared this movement as "foreign-inspired" and advised "the Muslim Conference to keep away from it" (Hussain et al., 2019). This stance of Jinnah portrayed him as anti-Kashmiris and it also damaged Muslim Conference's claimed image as the only Muslims' representor (Chandel, 2017; Bhat, 2017; Braithwaite \& Dcosta, 2018; Buzan, 2011).

Figure 2. Kashmir territories profile

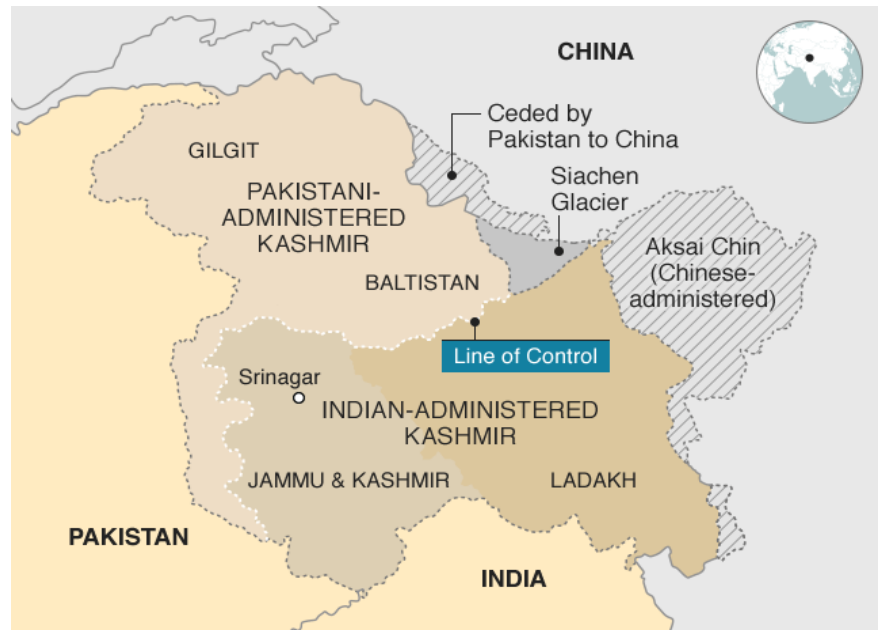

Source: (BBC, 2019)

At the time of independence, 562 odd princely states were supposed to join either of the two countries. Kashmir was the largest princely state. It has an area of $84,471 \mathrm{sq}$. miles $(218,800 \mathrm{sq} \mathrm{km})$. Due to demographic and religious compositions, it was suited to join Pakistan but the Maharaja being a Hindu could not accede to Pakistan as the country was founded in the name of Islam. He was also unable to accede with India and the main reason for that because of Nehru and the Congress as both were the "friends of his biggest enemy, Sheikh Abdullah." He, therefore, had intentions to make Kashmir as "independent state" (Hussain et al., 2019; Aurangzeb et al., 2020).

Kashmir had proximity to "China, Russia, and Afghanistan and remained a part of Silk Route." It could secure the Indian northwestern border as a Muslim majority state. Its accession to India was thought to "fortify the idea of a secular India" (Hussain et al., 2019; Thomas, 1991). It was the ancestral homeland of Nehru who was very much eager to make Kashmir a part of India. Then Gandhi also visited Kashmir and persuaded the Maharaja for accession to India. Further, the prime minister of Kashmir R. C. Kak, who favored the accession to Pakistan, was replaced by the Lord Mountbatten on the dictation of Nehru and Gandhi, with J. Singh and then by M. C. Mahajan (previous Hindu member of Radcliffe Commission, a loyal Arya Samajist) who immediately started working on Kashmir's accession to India. At that time, Sheikh Abdullah was in prison and Nehru thought as the only person suitable for "Kashmir's accession to India." On Nehru's request, Patel wrote a letter to Maharaja and Sheikh Abdullah was released on $29^{\text {th }}$ of September while other leaders of Muslim Conference were still behind the bars (Hussain et al., 2019). When he was released, he, during a speech at a rally in Hazaribagh Srinagar on 2nd October, raised the slogan of "freedom before accession" and the "supremacy of the will of people," which resultantly raised a question about the fate of Kashmir because he camped in Delhi. His mood of speech indicates that his inclination was not to Pakistan. He was a big critique of two-nation theory (Sherwani, 1999; Sehgal, 2011). Congress, therefore worked in full thrust for the accession of Kashmir to India while the Muslim League could not give much time to Kashmir issue due to demographic composition of the state. Reps were sent to Shaikh Abdullah by Jinnah to negotiate with him he repeated the slogan of "freedom before accession" although it was revealed that out of $77.06 \%$ of the Muslim population of the state, $47 \%$ were pro-Pakistan and therefore 
against the leadership of Sheikh Abdullah. Therefore, Maharaja's decision of accession of Kashmir to India was against the will of Kashmiris (Sherwani, 1999). Resolutions of Security Council, passed on August 13, 1948 and January 5, 1949, ensured the people of Kashmir about their "right to determine the future of their state by holding an impartial plebiscite" (Hussain et al., 2019). In this regard, the Security Council also established a commission titled "United Nations Commission for India and Pakistan" to resolve the Kashmir conflict (Sherwani, 1999; Sehgal, 2011).

\section{Situation of Kashmir after partition of Pakistan and India}

The situation of Kashmir with respect to claims and occupations on various parts of the valley is explained in Figure 3. The state is divided into various parts in occupation of one while claimed by the other country. The Kashmiri people as a result of their demand for separation from India are experiencing Indian occupation. They do not accept this status quo and many liberation movements in response to this are operating in the state. Indian forces have been adopting brutal ways to control the situation in the state and this is resulting in massive fatalities and injuries to the innocent people of the valley also. The United Nation Security Council has never taken serious action against the Indian government's refusal to the UN resolutions that were passed about the plebiscite in the state. The Indian government has imposed oppressive laws upon Kashmiris and their basic rights of independence and self-determination (Sehgal, 2011). Some of these laws are as elaborated:

i. The Jammu and Kashmir Public Safety Act of 1978: This act permits law enforcement authorities the detention of anybody who is suspected. This detention can be for a period of 2 years without any definite charge on the suspected person. This act is being abused by the security forces against children of 12 to 16 years of age merely because of their pelting stones on vehicles (Behera, 2016).

ii. The Armed Forces Special Powers Act (AFSPA): This act allows the Indian security forces "to maintain public order in disturbed places." For this purpose, they can search the suspected home and arrest anybody without any warrant. This act further bans "the gathering of five or more individuals" in that area and permits Indian Security Forces to even "open fire to scatter them" (Behera, 2016).

iii. Terrorist and Disruptive Activities Act of 1990: this act allows security forces to detain a person even if no charge of evidence is there about involvement in terrorist activities. The duration of this detention can be up to one year (Zulfiqar, 2016).

iv. Terrorism Act (POTA), 2002: This act defines a terrorist act as "Any act committed by lethal weapon" (Zulfiqar, 2016).

Figure 3. Kashmir Region

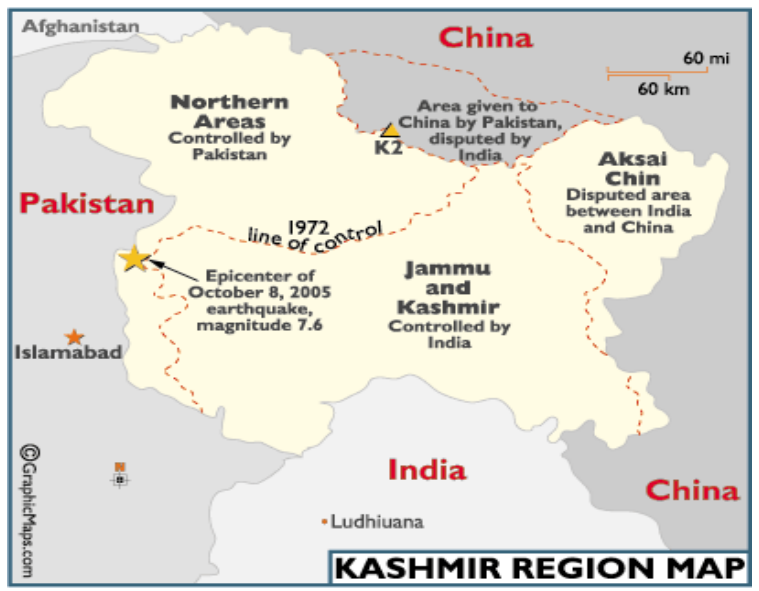

Source: (Rajput, 2011) 
Moreover, Article 370 of the Indian constitution which granted "an autonomous status to Kashmir," has been revoked by the present Prime minister of India. According to Article 35 (A), that was incorporated in the constitution of India in 1954, special rights were given to the permanent residents of Kashmir. With the passage of time, the posts of Kashmiri president and the prime minister were replaced by the governor and the chief ministers respectively and thus this special status of the state was terminated (Ahmar, 2017; Zulfiqar, 2016). The purpose of this revocation is to bring changes to the demography of Jammu and Kashmir "by creating Sainik Colonies and townships for the displaced Kashmiri Pandits." This is an illegal attempt according to the international laws i.e. Article 49 of the fourth Geneva Convention, as "the occupying power shall not deport or transfer part of its own civilian population into the territory it occupies." Syed Ali Gilani, the separatist Kashmiri leader, responded to this revocation that the Pandits have the right to settle back in their motherland but their settlements in private colonies would definitely "change the ethnic demography of the state and generate a continuous communal division in Kashmir" which is not acceptable (Hussain et al., 2019 \& 2009).

Kashmir issue is not merely the root cause of tensive relations between India and Pakistan but it is a nuclear disaster waiting to happen any time (Figure 4) After the partition, there have been various struggles against the Izndian occupation. Major revolts of 1953, 1964, 1988-2000, 2010 and 2016 have happened in the state. The Indian Security Council have been unable to solve Kashmir dispute and that has instigated India to commit the human right violation. It is reported that "during riots of 1989, almost 100,000 people were killed and 1000 people disappeared." Kashmir has become a substantial concern for regional and international security due to continuous insurgency (Hussain et al., 2019 \& 2009). Due to violation of the ceasefire, at Line of Control (LOC forthwith), 1040 civilian and 318 military casualties have happened during the last ten years (Hayat, 2018). Separatist commander Burhan Wani was also killed in 2016, which resulted in a huge stream of violence among Kashmiri civilians. Despite the curfew, people were on road agitating his killing which resulted in further "killing of 36 civilians and 1500 injuries only 6 days after his funeral." During the next four months, approximately "75 Kashmiris lost their lives and more than 5000 were severely injured." Use of non-lethal pellet guns by security forces resulted in serious eye injuries in almost 1300 Kashmiris that included children (BBC, 2019).

Figure 4. A brief history of Kashmir between Pakistan and India
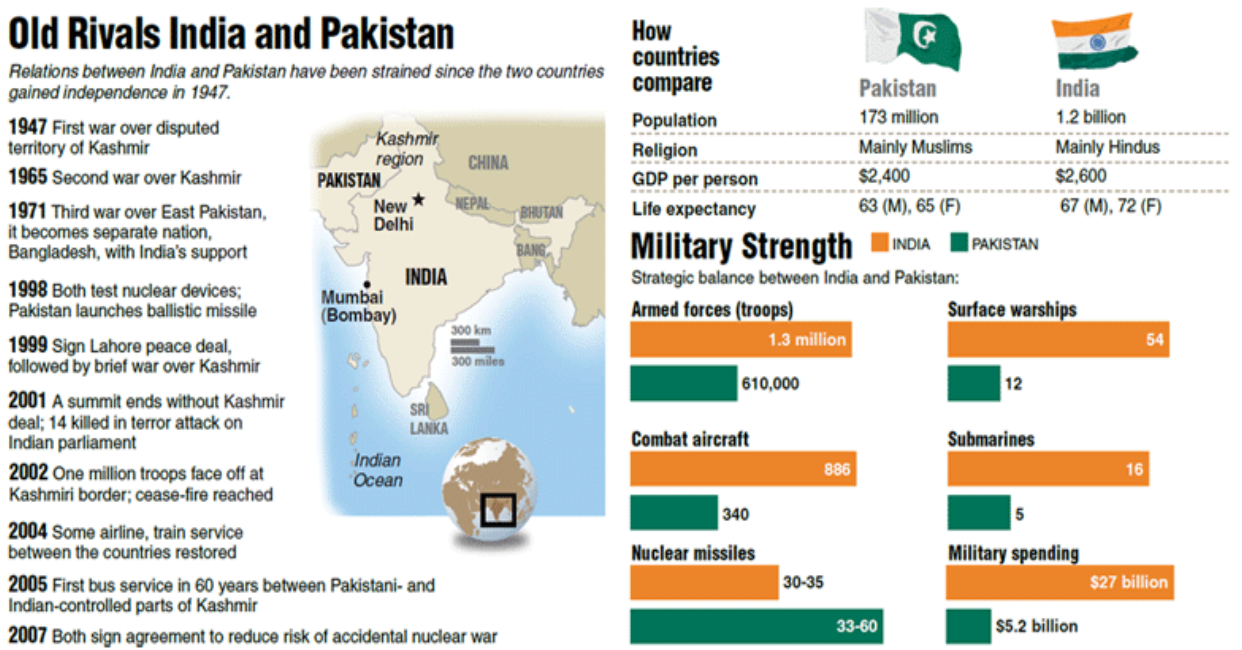

Source: (Macro Ops, 2016)

Pakistan is apprehended that sooner or later; India "will repudiate to negotiate the Kashmir issue bilaterally." There is a growing "asymmetry in negotiation dynamics," e.g. economic or military, between India and Pakistan. This asymmetry is evident from "emerging geostrategic relationships of India with Iran, the US and Afghanistan" (Hussain et al., 2019; Solangi, 2019). India has also succeeded in "gaining a foothold in Baluchistan and FATA (Federal Administered Tribal Areas of Pakistan)." These two areas are very important for Pakistan's economy and the transit routes towards China and Central Asia. Chinese incursion in Galwan 
Valley may also be due to India's continuous efforts to impact the Chinese economic interest in these areas (Hussain et al., 2019; Ahmed et al., 2020). Pakistan's water scarcity is another concern of Pakistan to solve Kashmir issue at an immediate basis. This water scarcity is worsened by Indian aggression there is "a continuous threat to Pakistan that India may divert the flow of Indus River and its tributaries" (Cheema, 2015 \& 2016). Pakistan has consistently attempted to seize Kashmir from India by "embracing discretionary just as military methodologies." For India, bowing to Pakistan's addition of Kashmir is hurtful to its mainstream structure and will "trigger other secessionist developments."

India arranged its military with present-day strategies after the 1962 war with China and astounded Pakistan by sending the main part of infantry on the bleeding edge of Kashmir outskirt. Pakistan made a few vital suspicions to drove war in Kashmir during 1965 which refuted and thus Pakistan confronted a great deal of emergency particularly the withdrawal of East Pakistan after 1971 (Mustafa, 2014). In 1972, through the Simla Agreement, India and Pakistan agreed to solve their disputes by negotiation and respect the LOC. After the end of 1971 war, India emerged as a dominant power in South Asia and the Kashmir dispute was totally frozen by the Simla Pact because India "claimed that the UN resolutions about Kashmir have supplanted because of the formation of LOC." India also took control of Tithwal and Kargil, strategically most significant areas. Furthermore, India also got a diplomatic victory over Pakistan due to the agreement that the bilateral disputes would be solved through negotiations (Hussain et al., 2019).

Figure 5. Division of the State (Macro Ops, 2016)

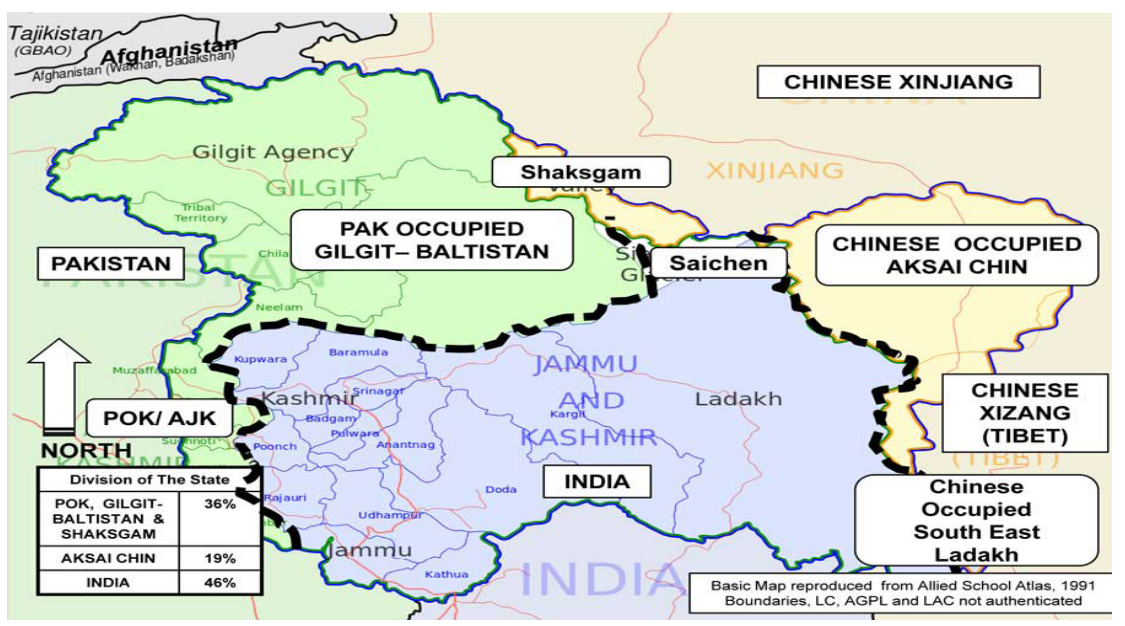

Source: (Macro Ops, 2016)

India's nuclear tests in 1974 intensified the Pakistan security concerns further but the bilateral relations remained peaceful until the soviet invasion in Afghanistan. During this invasion, Pakistan became a frontier allays of the US. The US provided Pakistan “\$ 3.2 billion for six years in terms of economic and military aid" (Epstein \& Kronstadt, 2013). This US aid “in bulk amount," helped Pakistan to build its army in a better and modern way and therefore Pakistan became confident to exploit India. In the 1980s, the mutual relations were further worsened because of "Siachen glacier, Sikh insurgency, nuclear issues and Bras stacks crisis" with Siachen disputes remaining the "major bone of contention during two decades and ended up after the Kargil war in 1999” (Hussain et al., 2019).

During the decade of 1980, the US and India, based on the information by their intelligence agencies, accused Pakistan of developing nuclear weapon capabilities which were speculated by the international community that India had a "plan to attack Pakistan's Kahuta nuclear center like "Operation Opera." Operation Opera was a surprise Israeli airstrike carried out on 7 June 1981, which destroyed an Iraqi nuclear reactor under construction near Baghdad, Iraq (Hussain et al., 2020). However, an effort of goodwill and friendship was surfaced when India and Pakistan signed an agreement according to which they decided not to spoil each other's nuclear program. This move was destroyed when India military exercises in a large series on the Rajasthan border. These exercises were meant to "threat Pakistan" and "put pressure on Pakistan to stop supporting Khalistan movement" and therefore sounded like an alarm of war (Kanwal, 
2014; Mukherjee, 2016; Chawla, 2017; Hussain et al., 2019).

During the decade of 1990, the bilateral relations between Pakistan and India further deteriorated due to the Kashmir crisis and Pakistan's nuclear tests and Kargil war. After the 1987 Jammu \& Kashmir legislative elections, armed resistance in Kashmir started, and "Pakistan's support of the militants and insurgency" resulted in "massive evacuation of Kashmiri pundits from the valley" (Hussain et al., 2019). In 1992, India and Pakistan agreed that they will provide advanced notification to each other for military exercises and will not violate each other's airspace boundaries or use chemical weapons against each other. Later, both India and Pakistan detonated nuclear devices and were subject to international sanctions. In 1999, the Kargil war erupted and this "harmed the diplomatic objectives of the Lahore Declaration," which was considered "a milestone in Indo-Pak bilateral relations" (Hussain et al., 2019). Moreover, "a full-scale military operation was conducted in Indian Occupied Kashmir after the attack on Kashmir legislative assembly in 2001" and after that when there was "an attack on the Indian Parliament in December 2001," it resulted in an armed standoff between the two countries at LOC (The Express Tribune, 2015). This standoff ended after external mediation in 2002 and again a ceasefire agreement was signed in September 2003 during the UN General Assembly meeting (Hussain et al., 2019).

Despite announcing in November 2004 that India was going "to reduce the troops' deployment of in Kashmir," India redeployed about 5000 troops in Kashmir in 2006 and also formed "the joint anti-terrorism mechanism in September 2006." As a result of an attack on Samjhauta Express (Samjhauta means "agreement, accord and compromise" in both Hindi and Urdu. The railway service between the two countries was named this.) in February 2007, 68 people were killed. India signed the "Turkmenistan Afghanistan Pakistan gas pipeline project" in 2008, and blamed Pakistan for attacking the Indian embassy in Kabul, Afghanistan. The 26/11 Mumbai attacks further ceased Indo-Pak relations because, in this attack, more than 160 people were killed. After that, there had been an occasional exchange of fire at LOC but both countries also attempted to resume the substantive peace talks. There happened further attempts of better relations like in 2014, Pakistan accepted the invitation of the swearing-in ceremony of Indian Prime Minister Modi and as a goodwill gesture in response to this invitation, released 155 Indian fishermen. Moreover, a formal meeting was held between "premiers in Russia at the $15^{\text {th }}$ SCO summit" and Prime Minister Modi paid a surprise visit to Lahore at the occasion of Prime minister Nawaz Sharif's birthday and his granddaughter's wedding. During this time, "sweet were exchanged between Pakistan Rangers and Indian BSF (Border Security Forces of India) on the border" that also "played some role in defusing the tension" between the two countries (Hussain et al., 2019).

However, according to Defense Ministry of Pakistan, "during May 2014 to December 2015, India violated the ceasefire 247 times which killed 39 Pakistani civilians" and in January 2016, "gunmen-attack on the Indian Pathankot airbase" and the "September 2016 terrorist invasion of Uri army base killing 18 Indian soldiers" were also blamed on Pakistan (Panda, 2016) after which no or very little improvement in bilateral relations is observed. The revocation special status of Jammu and Kashmir by the Indian government and the Chinese excursions in Galwan valley are two other important events that have impacted the bilateral relations of India and Pakistan further (Aurangzeb et al., 2020). India claims Kashmir in its entirety and is not ready for any negotiation over it nor is it ready to accept any other country to play mediating role towards the solution of Kashmir. In this regard, India has already refused the US offer for mediation over this issue despite that India is the strategic ally of the USA. This makes Kashmir not only the Indo-Pak rivalry but now India-China relations are also being affected due to this issue (Mehboob, 2020; Asadullah et al., 2020). Still, India can take advantage of the problems which Pakistan is facing internally and externally (Aftab et al., 2020; Amir, 2018; Asadullah et al., 2020) and influence the circumstances that may lead to the solution of Kashmir according to its stance.

\section{Conclusion}

On the basis of the foregoing historical analysis, following points are concluded:

The rivalry between India and Pakistan may be due to many reasons but the Kashmir issue is the most important reason for that. This rivalry is not only dangerous for both countries but also is a constant threat 
to the peace and security of South Asia. This security situation bounds the other states of the region also.

The rivalry has linked up the national security of India and Pakistan with each other. Their peace and security cannot be considered independently principally due to the Kashmir issue.

India is dominant over Pakistan in the region in terms of population, military, and economic capabilities but Pakistan has constantly denied the Indian domination and has attempted to gain a balance of power. In this regard, Pakistan is trying to gain collaboration with the US, China, Gulf, and Middle East states to secure economic and military powers. However, the aid from Islamic states is purely economic but the alliance with the US and China has given Pakistan both economic and military powers.

The extended conflicts over the Kashmir issue between India and Pakistan are creating hurdle towards the improvement in their bilateral relations as they are both nuclear states with constantly modernizing their respective nuclear programs and producing a threat of sudden war.

A permanent solution to the Kashmir issue is necessary for that the regional peace in the region can be ensured and stabilized.

Simla Pact is a hurdle between the solution of Kashmir issue as Pakistan is willing to solve the dispute under the instructions giving by United Nation but it is not possible due to Simla Pact because of which India resists each and every effort to address the issue bilaterally.

Pakistan has not been effectively able to raise the Kashmir issue at global forums. This lacking of Pakistan is another hurdle towards the solution of Kashmir issue.

Pakistan requires active networking to assemble public opinion in its favor with regards to Kashmir stand and influence the policymakers.

Policymakers on Pakistan's side need to take serious actions to resolve the Kashmir issue and influence the UN Security Council's permanent and non-permanent members. This is necessary because these members play an authoritative role in the solution to such issues.

Confidence building measures across the LOC and the ceasefire agreements between India and Pakistan have worked for the people of Kashmir but their failure in capitalizing the bus service across the LOC and their deviation from the ceasefire agreement has created doubts about them in the minds of Kashmiris. The firing incidents across LOC are multiplying these suspicions.

Pakistan has been alleged by India of supporting terrorism in India. The militancy in Jammu \& Kashmir is also blamed on Pakistan. In this way, the genuine Kashmir movement and the right of self-determination of Kashmiris have been politicizing by India.

Pakistan, which has always been denying these allegations by India, considers militancy in Kashmir a collective result of Indian oppressive policies and the denial of Kashmiris' right of self-determination. The discriminative economic policies of India towards the state of Jammu and Kashmir is also considered another reason for militancy in Kashmir.

India and Pakistan are deep-rooted enemies because of historical, ideological, and regional reasons and this enmity between the two countries is unlikely to vanish soon.

Kashmir issue is adding fuel to the fire. India has always challenged the ideology of two nations which formed a base for the founding of Pakistan. Pakistan, on the other hand, is exposing Indian domination in South Asia. Both countries are acquiring nuclear capabilities and the arms race between them is further is thickening the layers of enmity rather than resolving the Kashmir dispute. Three major wars and Kargil Conflict have disturbed the social fabric and economic structure of both countries.

Pakistan is now supporting the Kashmir movement only verbally and morally rather through means of militancy but this issue itself demands a multidimensional approach. 


\section{REFERENCES}

Aftab, N., Khan, M. F, \& Ali, S. (2020). Pakistani Bureaucracy: Crisis of Governance, Prospects and Recommended Reforms. Electronic Research Journal of Social Sciences and Humanities, 2 (II), 61-75. http://www.eresearchjournal. $\mathrm{com} /$

Ahmar, M. (2017). Indian secularism and the erosion of article 370. Journal of Pakistan Vision, 18 (1), 1-12. http://pu.edu. pk/home/journal/12/V_18_1_2017.html

Ahmed, T., Ali, S., Ali, M.S., Rahman, W., \& Amir, S. (2020). Face-off between India and China in Galwan Valley: An Analysis of Chinese Incursions and Interests. Electronic Research Journal of Social Sciences and Humanities, 2 (III), 38-50. http://www.eresearchjournal.com/

Ali, S., \& Saeed, A. (2019). Kashmir Dispute and Challenges to the National Security of Pakistan: An Analysis. Electronic Research Journal of Social Sciences and Humanities, 1 (II), 61-77. http://www.eresearchjournal.com/

Amir, S. (2018). Characteristics of Future Military Leadership. Electronic Research Journal of Behavioural Sciences, 1(2018), 5-16. http://erjbehaviouralsciences.com/

Asadullah., Karim, D., Mehmood, S., Ali, S. \& Amir, S. (2020). Sino-Pakistan Relations during Covid-19: The Weakest Links. Praxis International Journal of Social Science and Literature, 3 (6), 1-6. https://www.pijssl.com/

Aurangzeb, M., Akhtar, S., Ali, K., Hayat, N., \& Amir, S. (2020). Kashmir Struggle for Freedom: Proposed Solutions. International Journal of Social Sciences and Humanities, 5(1), 61-68. http://www.eresearchjournal.com/

BBC. (2019). Kashmir territories profile. Retrieved July 21, 2020 from https://www.bbc.com/news/world-southasia-11693674

Behera, N. C. (2016). The Kashmir conflict: Multiple fault lines. Journal of Asian Security and International Affairs, (3)1, 41-63. https://journals.sagepub.com/home/aia

Bhat, S. A. (2017). Jammu and Kashmir on the eve of partition- A study of political conditions. South Asian Studies: A Research Journal of South Asian Studies, 32 (2), 285-295. https://www.tandfonline.com/toc/csas20/current

Braithwaite, J., \& Dcosta, B. (2018). Recognizing cascades in India and Kashmir. In J. Braithwaite \& B. Dcosta (Eds.), Cascades of Violence: War, Crime and Peacebuilding Across South Asia (1st ed., pp. 177-270). Acton ACT, Australia: ANU Press. https://www.jstor.org/stable/j.ctt22h6r7h

Buzan, B. (2011). The South Asian security complex in a decentering world order: Reconsidering regions and powers ten years on. Millennium Journal of International Studies, 48 (1), 1-19. https://journals.sagepub.com/toc/mil/48/1

Chandel, N. (2017). Jawaharlal Nehru's intervention in Kashmir till 1947. World Wide Journal of Multidisciplinary Research and Development. 3 (11), 85-90. http://wwjmrd.com/

Chawla, M. I. (2017). The Khalistan movement of 1984: A critical appreciation. South Asian Studies: A Research Journal of South Asian Studies, 32 (1), 81-90. https://www.tandfonline.com/toc/csas2o/current

Cheema, M. J. (2015). Pakistan-India conflict with special reference to Kashmir. South Asian Studies A Research Journal of South Asian Studies, 30 (1), 45-69. https://www.tandfonline.com/toc/csas20/current

Cheema, P. I. (2016). Resolving Kashmir dispute analyzing various approaches. Margalla Papers, 20(1), 23-36. https:// ndu.edu.pk/issra/issra_pub/articles/margalla-paper/Margalla-Papers-2016/2_Dr_Pervaiz_lqbal_Cheema.pdf

Epstein, S. B., \& Kronstadt, K. A. (2013). Pakistan: U.S. foreign assistance. Current Politics and Economics of the Middle East, 4(3), 575. https://novapublishers.com/shop/current-politics-and-economics-of-the-middle-east-2/

Hayat, Z. M. (2018). Inaugural address. In S. S. Aneel (Ed.), Regional Dynamics and Strategic Concerns in South Asia (pp 8-15). Islamabad: Islamabad Policy Research Institute (IPRI). https://www.csis.org/analysis/south-asia-regional-dynamics-and-strategic-concerns

Hussain, S. S., Mustafa, G., Imran, M., Nawaz, A., \& Sarkaria, M. K. (2009). Powerful pawns of the Kashmir conflict: Kashmiri Pandit migrants. Asian and Pacific Migration Journal, 18(2), 197-230. https://journals.sagepub.com/ home/amj

Hussain, S. S., Mustafa, G., Imran, M., \& Nawaz, A. (2019). The Indo-Pak Rivalry and the Kashmir Issue: A Historical Analysis in the Security Context of the South Asia. Journal of Political Studies, 26 (2), 73-84. https://www. journalofpoliticalstudies.com/

Kanwal, L. (2014). Kashmir Issue and the Inter-Provincial Politics of Pakistan 1947-1969. Pakistan Vision, 15 (2), 81-97. http://pu.edu.pk/home/journal/12

Kashmir Global. (2012). Clashes between protesters and Indian forces erupted in Srinagar \& other parts of Kashmir. Retrieved December 4, 2020 from https://kashmirglobal.com/2012/10/27/clashes-between-protesters-and-indian-forces-erupted-in-srinagar-other-parts-of-kashmir.html

Macro Ops. (2016). India: Kashmir Conflict Heating Up. Seeking Alpha. Retrieved July 21, 2020 from https://seekingalpha.com/article/4023912-india-kashmir-conflict-heating-up 
Mehboob, S. (2020). Kashmir in murky waters. The Nations. Retrieved July 21, 2020 from https://nation.com.pk/15Jul-2020/kashmir-in-murky-waters?show=preview

Mukherjee, K. (2016). Indo-Pak Relations and the Kashmir problem: From 1947 to the present day. Journal of Borderlands Studies, 31 (4), 497-520. https://www.tandfonline.com/rjbs20

Mustafa, G. (2014). The issue of prisoners of war (POWS), 1971 and recognition of Bangladesh. International Journal of Business and Social Research, 4 (3), 114-118. www.thejournalofbusiness.org

Naz, S. (2019). Pakistan's Military Strategy: Challenges and Response. Electronic Research Journal of Social Sciences and Humanities. 1(1) 58-73 http://www.eresearchjournal.com/

Panda, A. (2016, September 19). Gurdaspur, Pathankot, and now Uri: What Aare India's options?. The Diplomat. Retrieved January 15, 2019 from https://thediplomat.com/2016/o9/gurdaspur-pathankot-and-now-uri-whatare-indiasoptions/.

Rajput, K. (2011). The Blame Game. Peacecoalition. Retrieved July 21, 2020 from https://peacecoalition.wordpress. com/2011/04/08/the-blame-game/

Sehgal, R. (2011). Kashmir conflict: Solutions and demand for self-determination. International Journal of Humanities and Social Science, 1 (6). 188-195. http://ijhssnet.com/

Sherwani, L. A. (1999). Kashmir's accession to India re-examined. Pakistan Horizon, 52(4), 49-77. https://www.jstor.org/ journal/pakistanhorizon

Showkin, S. (2015). Kashmir issue was 'Settled' in 1947. Why then, is the conflict still on? Retrieved July 21, 2020 from https://www.scoopwhoop.com/news/kashmir-issue-no-resolution/

Solangi, S. (2019). Development of Chabahar Port: Challenges and Implications for Pakistan and CPEC. Electronic Research Journal of Social Sciences and Humanities. 1(1), pp. 48-57. http://www.eresearchjournal.com/

The Express Tribune. (2015, December 5). India violated truce over 240 times, senate panel told. Retrieved April 15, 2020, from https://tribune.com.pk/story/1004159/under-modis-govt-india-violated-truce-over240-times-senatepanel-told/.

Thomas, R. C. G. (1991). Why India resists Kashmiri separatism. The Christian Science Monitor. Retrieved April 5, 2019, from https://www.csmonitor.com/1991/0722/22192.html.

\section{AUTHORS}

Muhammad Asadullah. Master in International relations and currently working as a research assistant with a professor at the university. He is perusing his MS in IR; therefore, his research Interests are IR, Current Affairs, and geopolitics.

Dawood Karim. Master student at the university. His specialization is IR. His research interests are IR, defense studies, and geopolitics.

Shamaila Amir. Ph.D. student at the university. Her special interests are linguistics, literature, IR, and Psychology

Fayyaz Ahmad. Master student at the university. His special interests are behavioral sciences and International relations.

\section{Conflict of interest}

No potential conflict of interest is reported by the authors.

Funding

No financial assistance from parties outside this article.

Acknowledgments

$\mathrm{N} / \mathrm{A}$ 